\title{
Italian in Switzerland: Statistical Data and Sociolinguistic Varieties
}

\author{
Bruno Morettia \\ Matteo Casoni ${ }^{b}$ \\ Elena Maria Pandolfic
}

\begin{abstract}
This contribution presents the different situations of Italian in the cantons of Ticino (where a gradual reduction in dialectophony is taking place) and Graubünden (where the dialect is being preserved), as well as the standardisation of Swiss Italian, which is taking place through the process of "standard by mere usage" (AMMON, 2003, p. 2). A number of important theoretical concepts are brought up to date here in a very enlightening way: the concept of dilalie (BERRUTO, 1987) to describe the functional overlap between two varieties of a language, the pluricentricity of languages (CLYNE, 1989), models of standardisation of pluricentric languages (AMMON, 1989) and the representation of the bicentricity (AUER, 2005) of Italian (Italy and Switzerland).
\end{abstract}

Keywords: Swiss Italian. Dialect.

Standardization. Pluricentricity.

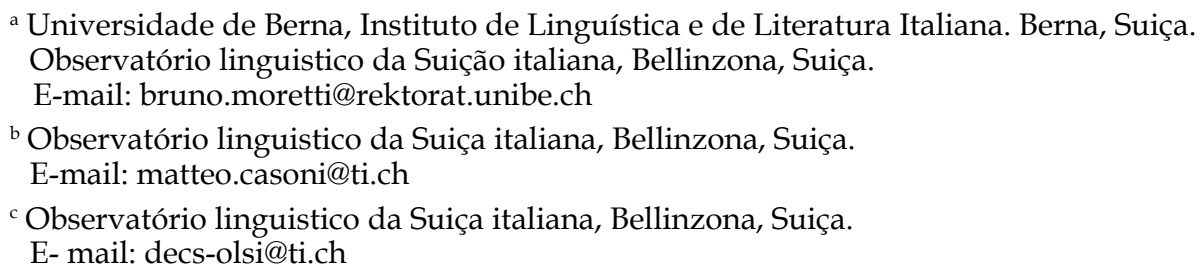

\section{How to cite:}

Moretti, B.; Cassoni, M.; Pandolfi, E.M. Italian in Switzerland: Statistical Data and Sociolinguistic Varieties. Gragoatá, Niterói, v.26, n.54, p. 252-293, 2021. <https://doi.org/10.22409/gragoata.v26i54.46913> 
${ }^{1}$ For the position of Italian in relation to other national and non-national languages see Table 1 of the Introduction.

${ }^{2}$ In addition to the Constitution and the regulations defined by federal laws, mention should be made of the exceptionally rich range of radio and television services on offer: 2 television channels, 3 radio stations and 2 Italianlanguage multimedia portals (www.rsi.ch).

${ }^{3}$ For the relationship between the formal status and demography of national languages see Berthele (2016). The status and vitality of Italian as a minority national language in the context of Swiss plurilingualism is also monitored and measured, for example, through the Vitality Index for Italian in Switzerland (cf. MORETTI; PANDOLFI, 2011; MORETTI et al., 2011; PANDOLFI et al., in prep.).

\footnotetext{
${ }^{4}$ The change in survey modalities, limited after 2000 to the population aged 15 or over, has consequences for the figures of the past as well. The Federal Statistical Office adapted the data from 1970 to 2000 to the new modalities (to improve comparability), but this was not done for older results. Nevertheless, we would like to present the 1950 and 1960 data as well, on the one hand because they are fundamental to the understanding of migration dynamics and, on the other hand, because the differences due to the homogenization of the data according to the new modalities are a few tenths of a percentage point.
}

\section{Italian in Swiss plurilingualism}

Although Italian has formally the same status as the other national languages (regardless of demography ${ }^{1}$ ) and the Italianspeaking community is one of the best protected national language minorities ${ }^{2}$, as a minority it is undoubtedly often marginalized in socio-economic terms compared to German and French as majority national languages and English. ${ }^{3}$ As far as demography is concerned, Italian has experienced the greatest variation across the decennial censuses of the Federal Statistical Office (Table 1). The reason for this is to be found in the events of Italian immigration. ${ }^{4}$

Table 1 - Italian as the main language from 1950 to 2010-2012, national results in percentages.

\begin{tabular}{ccccccc}
\hline $\mathbf{1 9 5 0}$ & $\mathbf{1 9 6 0}$ & $\mathbf{1 9 7 0}$ & $\mathbf{1 9 8 0}$ & $\mathbf{1 9 9 0}$ & $\mathbf{2 0 0 0}$ & $\mathbf{2 0 1 0 - 2 0 1 2}$ \\
\hline 5,9 & 9,5 & 11,1 & 9,3 & 8,0 & 6,8 & 8,4 \\
\hline
\end{tabular}

Source: Swiss Federal Statistical Office

Table 1 clearly shows the influx of Italian workers in the 1950s and 1960s, which brought the percentage of Italian workers to a peak in 1970, with a gradual and relatively constant decline in the years to follow. The percentage for 2010-2012, higher than that of 2000, seems to oppose this trend, but this is in fact a consequence of changes in the census system. Indeed, it was not allowed to indicate several main languages in the census responses until 2000, while since then this possibility has been available (which also allows for a better consideration of plurilingualism at this level ${ }^{5}$ ). An obvious consequence of this is visible in the fact that people, especially second and third generation immigrants - who would have declared the language of their home as their only main language - can now also add Italian. Beyond the impossibility of directly comparing the data for 2010-2012 with the previous figures, these declarations of Italian language proficiency are very interesting, as they show the maintenance (at different levels of proficiency) of Italian or at least a willingness to declare Italian also as a main language. If we try to capture a percentage that is actually comparable to that of 2000 , we receive a percentage 
${ }^{5}$ This is a 'strict' conception of individual

bilingualism: the main language concerns only the skills of native or 'nearnative' speakers (see: BERRUTO; MORETTI SCHMID, 1988; BERRUTO, 2003) and excludes partial and/ or passive skills and bilingual repertoires with diglossia or dilalie.

${ }^{6}$ Since we do not have suitable data available for 1990 and 2000 which would guarantee better comparability from a population point of view, we limit ourselves here to a presentation of the available data with the intention of simply showing the importance of migration for the presence of Italian outside its traditional territory and the decline between 1990 and 2000.

${ }^{7}$ In order to underline the importance of the extraterritorial component in relation to the territorial component as far as Italian is concerned, it is sufficient to take into account the fact that the two most important national languages in terms of the number of speakers, German and French, are present above all as main languages in their respective linguistic regions. Outside its territory, German is indicated as the main language only by $2.3 \%$ of the total population (while the other 63\% who indicate it as the main language live in the German-speaking territory). The

corresponding figures for French indicate 20\% within the French-

speaking territory and $2.6 \%$ outside it. of about $6.2 \%$, thus showing us that the decline continues all the same.

These dynamics of growth and decline of the Italian language show the complexity and variation of the situation of the Italian language in Switzerland, divided into its fundamental components of Italian in the territories of Italian-speaking Switzerland and Italian linked to Italian immigration. Table 2 illustrates these dynamics and shows the change between 1990 and 2000 with a major presence of Italian speakers in Italian-speaking Switzerland compared with those outside the territory in 2000. The figures for 2010-2012, on the other hand, are influenced by the problem of the possibility of indicating several languages, which motivates an increase and constitutes another type of information, incomparable in this form to the figures for 1990 and $2000^{6}$.

Table 2 - Territorial distribution of Italian speakers from 1990 to 2010-2012, percentage of the total population.

\begin{tabular}{lcc}
\hline & Italian Switzerland & Other linguistic regions \\
\hline 1990 & 3,6 & 4,0 \\
2000 & 3,7 & 2,8 \\
$2010-2012$ & 4,0 & 4,4 \\
\hline
\end{tabular}

Source: Swiss Federal Statistical Office

These simple percentages ${ }^{7}$ illustrate how the complex situation of Italian in Switzerland shows, from a demographic point of view, different trends in the two main types of situation. Italian in Italian-speaking Switzerland shows a general stability, untouched by the phenomena of decline or by other elements which could constitute negative consequences for this language, while Italian outside the traditional territory (from a demographic point of view mainly linked to migration) is responsible for the decline observed at a general level. In this sense, the 'traditional' Italian of Switzerland is demographically stable, which is also proved by the percentages of Swiss nationals only, which have been stable for several decades. However, the overall percentage of Italian speakers shows a steady decline (which will probably stop more or less at current figures). 
The federal censuses are not limited to the question on the main language, but also require self-declarations concerning specific areas of family and work. In the first case, Italian is indicated by $8.3 \%$ of the total population (subdivided into $3.5 \%$ within the Italian language region and $4.8 \%$ outside it). In the second case, Italian is indicated by $8.7 \%$ of the total population (subdivided into 3.5\% in the Italian speaking region and 5.2\% outside the Italian speaking region). Even if the differences are minimal, they partially contradict the image of Italian as the family language (as a 'private' heritage of migration) and show its significant presence in the field of work, also outside the Italian-speaking part of Switzerland. The interest of these data is not only linked to a punctual observation of particular fields, but they become even more significant when we take into account the fact that already in the censuses of previous decades multiple responses were admitted in these cases, which allows a more assured comparability of the data. In relation to family behaviour, for example, Italian employment declarations increased from 2000 to $2010-2012$ by 1.5 percentage points (the previous percentage was 9.8\%).

The data presented so far take into account only those speakers who have a full command of Italian (main language) or who usually use it in the family or at work. In order to complete the picture of Italian-speaking Switzerland, it is also necessary to consider the situation of the plurilingual repertoires of speakers with partial competence (at different,

8 The survey on language, religion and culture (ELRC) is carried out every five years, the first time in 2014, based on a much smaller sample (around 16,000 people) than the annual structural survey (RS). For statistical reasons, the result for the main language of the ELRC in Table 3 differs (by tenths) from that of the RS. We use this result in order to be able to compare figures from the same survey. For a first analysis of the ELRC language data see Flaugergues (2016), see also Casoni; Christopher; Pandolfi; Bruno (in preparation). even minimal levels) in Italian. The ELRC 2014 thematic survey ${ }^{8}$ offers results on 'secondary languages', i.e. languages which are not declared as the main language, but which are more or less understood or even spoken by the interviewee. Table 3 shows a comparison of the figures for Italian as a main language and as a secondary language at national level and distinguishing between Italian-speaking and non-Italian-speaking regions.

Taking into account the problems of a survey based on a small sample, we note the fact that 598,181 people $(8.8 \%$ of the national population) declared Ital ian as their main language, while 2,277,360 declared it as a secondary language. If we add these two figures together, we see that in Switzerland 2,875,541 people (42.5\% of the reference population) declared that they (also) possess Italian as a language of their linguistic repertoire, at different levels of competence. Outside the Italian-speaking 
Table 3 - Italian Lprinc and Lsec inside and outside the territory, absolute figures and percentage of the population.

\begin{tabular}{|c|c|c|c|c|c|c|c|}
\hline & \multicolumn{2}{|c|}{ Switzerland } & \multicolumn{2}{|c|}{$\begin{array}{l}\text { Italian-speaking } \\
\text { regions }\end{array}$} & \multicolumn{2}{|c|}{$\begin{array}{c}\text { non-Italian- } \\
\text { speaking regions }\end{array}$} & \multirow{2}{*}{$\begin{array}{l}\text { Tot. Italian- } \\
\text { speaking outside } \\
\text { of the territory } \\
\text { (Lprinc+Lsec) }\end{array}$} \\
\hline & Lsec & Lprinc & Lsec & Lprinc & Lsec & Lprinc & \\
\hline Italian & 2277360 & 598181 & 54645 & 252903 & 2207312 & 343782 & 2551094 \\
\hline$\%$ of pop. & 33,7 & 8,8 & 17,7 & 82,0 & 34,3 & 5,3 & 39,7 \\
\hline Population & \multicolumn{2}{|c|}{6760913} & \multicolumn{2}{|c|}{308436} & \multicolumn{3}{|c|}{6430317} \\
\hline
\end{tabular}

Source: Swiss Federal Statistical Office

territory, $34.3 \%$ of the population declared to have competence in Italian at different levels. This result is not surprising and rescales the frequent territorial monolingualism, observed by considering only the main languages (PANDOLFI; CASONI; BRUNO, 2016, p. 42-43) and represents, on the contrary, a Swiss linguistic landscape in which almost half of the resident population has at least minimal competence in Italian. Considering the results concerning vitality, we can affirm that a language which is more present in the individual repertoire and more used in different contexts, even with reduced competence, is also more present in the community due to its number of speakers, which is a fundamental aspect of its vitality. A constant presence of speakers with partial competence strengthens the communicative potential (AMMON, 2015, p. 63-75) of the third national language and contributes to the creation of communication networks across borders, to the cross-comprehension of language communities and to stronger social cohesion, which is in line with the goals which language policy and planning activities for minority languages seek to achieve.

The complexity of Italian in Switzerland does not, however, stop at the two fundamental sub-categories of Italian in Switzerland (that of Italian-speaking Switzerland and that of immigration), which are not at the same level, since the first is defined by territory and the second by nationality. To these two macro-types are added, in different ways, other forms of the presence of Italian, such as that in federal institutions or that due to the learning of Italian by non-Italian-speaking Swiss. Even the two basic components of Italian in Italian- 
speaking Switzerland and Italian for immigration are divided into several varieties. It is therefore more appropriate to distinguish first of all between territorial Italian and Italian outside the traditional territory. The complexity of this situation is represented in Figure 1, proposed by Berruto (2012) based on the model of Moretti (2005).

Figure 1 - Varieties of Italian in Switzerland

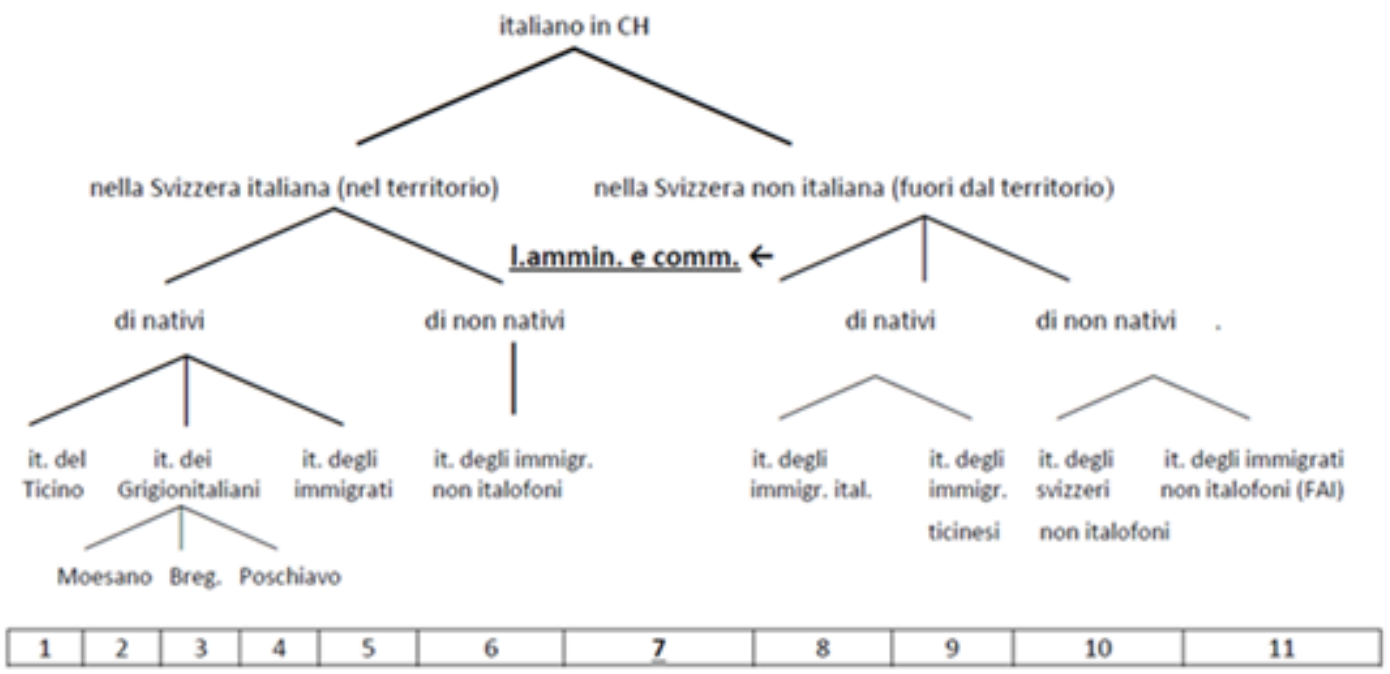

Source: BERRUTO, 2012.

In the version proposed by Berruto, eleven types of Italian present in Switzerland are distinguished, identified first of all by extralinguistic aspects, but for which characteristic linguistic phenomena are also to be identified. Among the fundamental parameters of differentiation are those of diatopy, which, for example, motivates the division of Italian-speaking Switzerland not only along cantonal borders but also within the Italian-speaking Grisons. The geographical separation of the Graubünden valleys and their socio-economic and demographic differences have linguistic consequences and justify such a distinction. Within Italian-speaking Switzerland we therefore see clear diatopic differences which result in different regional Italians. However, it must be borne in mind that in this case the diatopic variation is not only related to the spatial dimension, but also includes the different social 
and economic components of the groups present in the different locations. Diatopic varieties, at least in the case of geographically separated varieties such as those of Ticino, Val Poschiavo and Val Bergaglia, make it possible to identify the origin of the speakers with a fair degree of certainty (especially through lexicon and phonology, as indeed for regional Italians in Italy) and they therefore constitute different regional Italians.

\section{The Italian of immigration}

We could try to assimilate the Italian of Italian-speaking Switzerland to that of Italian speakers of Swiss nationality and the Italian outside Italian-speaking territories to that of Italian immigrants. However, there are also varieties such as those in numbers 5, 9 and 10 of Berruto's inventory which do not correspond to this simplification. A parameter to be added to this differentiation is therefore that of nationality which is linked, in a way that is sometimes difficult to evaluate and define, to other parameters such as, for example, those of place of birth, the composition of the family of origin, or the duration of migration. Often, the varieties of the inhabitants of Italianspeaking Switzerland who are of Italian nationality but who were born and raised in Switzerland are not differentiated from the varieties of Italian-speaking Ticinese or Graubünden speakers of the same age. Table 4 distinguishes (in absolute figures and as a percentage of the total population) between Swiss and foreigners in Italian-speaking Switzerland who indicated Italian as their main language. The last line shows the figures for people who did not indicate Italian as their main language but as the language used in the family or at work.

Another significant parameter for the differentiation of Italian varieties in Switzerland concerns the question of whether they are native or non-native speakers (within the territory of Italian-speaking Switzerland as well as outside it). Finally, even if this does not appear in Berruto's scheme, we could justify a further differentiation of the group of Italian immigrants into several linguistically relevant subcategories, distinguishing, for example, the first migration of the 1950s and 1960s from more recent migration. Numerous studies also highlight the differences between the first and second generation in the case of the first migration (today, especially 
${ }^{9}$ Initial considerations on the third generation can be found in Moretti (2005).

${ }^{10}$ See especially Rovere (1977), Franceschini; Müller; Schmid (1984), Schmid (1990), Berruto (1991a, b).
Table 4 - Italian speakers in Italian-speaking Switzerland by nationality, 2010-2012.

\begin{tabular}{lcc}
\hline Nationality & Occurrrence & Percentage \\
\hline Swiss by birth & 150719 & 2,3 \\
First-generation Swiss* & 49334 & 0,7 \\
Italian & 45554 & 0,7 \\
Other nationalities & 14754 & 0,2 \\
TOTAL & $\mathbf{2 6 0 3 6 1}$ & $\mathbf{4 , 0}$ \\
Non-natif speakers (non & 23218 & 0,4 \\
Lprinc) & & 0,5 \\
\hline
\end{tabular}

* The official name in Switzerland would be "naturalized Swiss".

Source: Swiss Federal Statistical Office.

an evaluation of the situation of the third generation of this migration should be considered ${ }^{9}$ ). Generally speaking, there is a rapprochement of the first generation to the Italian language - due to the distance of the region of origin and its dialect and a very strong presence of the typical features of popular Italian. For the second generation, in the 1980s and 1990s, in an almost paradoxical way, we note an advanced competence in Italian compared to that of the parents and phenomena which are clearly to be attributed to neo-standard Italian. ${ }^{10}$

The role of Italian immigration in Switzerland can be explained by a series of effects. For example, in the case of the Italian-speaking part of Switzerland we can conclude that Italian immigrants played a considerable role in the transition from dialect to Italian, although this has not been definitively proven. Italian was reportedly adopted, out of a need for communication, as a shared language in peer groups who spoke different dialects in the family - in a way comparable to the developments in the cities of Northern Italy (see Moretti, 1999 and here $\S$ 4.1.2). In addition, Italian immigration has created, as we have seen, a strong Italian-speaking presence outside the traditional Italian-speaking territory (which is the most macroscopic result) and finally, this strong presence of native Italian speakers has created opportunities for a (necessary) diffusion of Italian among non-Italian-speaking Swiss and immigrants with other languages of origin.

With regard to the Italian-speaking non-native Swiss, a distinction must be made between a transmission from the 
${ }^{11}$ According to the terminology of Whinnom (1971), tertiary hybridization is the phenomenon corresponding to the learning of a language by non-native speakers with the help of other non-native speakers. top (through the school and partly based on the image of Italy as a nation with a great cultural tradition, especially since the Renaissance) and a transmission from the bottom, linked to contact with the Italian immigrants of the second half of the 20th century. As Berruto (2012, p. 3) points out, studies analysing the Italian of the Swiss (especially of the Frenchspeaking Swiss) are lacking as well as those on the varieties of Italian-speaking Swiss who have emigrated to the other linguistic regions of Switzerland.

Varieties of non-Italian-speaking immigrants, on the other hand, are more studied, especially in the early 1990s. Berruto collects them in number 11 of his table and defines them as Fremdarbeiteritalienisch (FAI ("Italian of foreign workers"); cf. BERRUTO; MORETTI; SCHMID, 1990; BERRUTO, 1991a, 1991b; MORETTI; 1993). The interest of this variety is above all its spontaneous nature in conditions of sometimes very low input (and in some cases in situations of tertiary hybridization ${ }^{11}$ ). It has been noted that in these cases, pidginization phenomena can appear and distance the varieties in question from the target language. Studies on the current vitality of this phenomenon do not exist. It is certain that the strength of the diffusion of Italian has diminished with the new migrations (of people who are not speakers of Romance languages) and with the entry of the second generation of Italians into fields of work which are more qualified and different from the traditional fields of the first generation (this is linked in particular to the native competence in German or French of the Italian speakers who have grown up in Switzerland). However, immigrants from other origins who have developed satisfactory communicative skills in Italian are still common.

It is extremely difficult to base reliable observations on the census results and we must therefore wait for specific surveys. Table 5 below corresponds to Table 4 , but refers to the non-Italian-speaking regions of Switzerland. A comparison of the two tables highlights the salient aspect of the difference concerning the category of people who declared Italian as the language used but did not declare it as their main language (see the last line of the table). This group further reinforces the presence of Italian outside Italian-speaking Switzerland (among the speakers in question are certainly also those who use Fremdarbeiteritalienisch). The fact that 17,000 people of 
neither Italian nor Swiss nationality declared Italian as their main language is also worth mentioning.

Table 5 - Italian speakers outside Italian-speaking Switzerland by nationality, 2010-2012.

\begin{tabular}{lcc}
\hline Nationality & Chiffres absolus & Pourcentage \\
\hline Swiss by birth & 49126 & 0,7 \\
First-generation Swiss* & 63425 & 1,0 \\
Italian & 162442 & 2,5 \\
Other nationalities & 17616 & 0,3 \\
TOTAL & $\mathbf{2 9 2 6 0 9}$ & $\mathbf{4 , 4}$ \\
Non-natif speakers (non Lprinc) & 209507 & 3,2 \\
\hline
\end{tabular}

Source: Swiss Federal Statistical Office.

12 See for example Lurati (1976), Rovere (1982), Berruto (1984 - who prefers the adjective 'Swiss' - and 2012) and Egger; Ferrari (2016, with a focus on the language of the federal administration).

${ }^{13}$ The communication of institutions and companies often also takes place at an international level, in a context in which the English language therefore plays a central role alongside other languages.

\footnotetext{
${ }^{14}$ There are no speakers of federal Italian per se, if we exclude uses of the spoken-written language such as, for example, speeches by members of the government. From this point of view, federal Italian is formed as a standard language, through a process that develops artificially from above (for the concept of standard see BERRUTO, 2007).
}

\section{The federal Italian}

By "federal Italian" we mean here the variety of Italian produced by federal institutions and large companies (public and private) active throughout the national territory ${ }^{12}$. By 'Swiss', on the other hand, we refer to the variety of Italian spoken in Italian-speaking Switzerland (PANDOLFI, 2006, p. 11). Federal Italian, as a language that has been substantially translated, is very exposed to contacts with other national languages and English, ${ }^{13}$ both as a product of non-Italian speakers and through its influence on Italian speakers. The federal variety has a "transversal" and "superimposed" nature to other varieties of Italian in Switzerland (see Figure 1). It originates and is mainly written and comes into contact with the varieties of Italian of native and non-native speakers (within and outside the traditional Italian-speaking territory) through institutional communications and the mass media.

Federal Italian does not have a real community of speakers, ${ }^{14}$ its diffusion is therefore not measurable in demographic terms (number of speakers), but rather in terms of functional and institutional status, as the official language of communication of, and with, the federal authorities and large companies. From this point of view, federal Italian has a potential audience of 2,875,541 Italian speakers, i.e. the sum of all those who indicated Italian either as their main or secondary language in the Thematic Survey on Languages 2014 (see 
${ }^{15}$ To this figure which includes both native Italian speakers and those with partial competence in Italian and which only concerns Swiss territory - should be added Italian speakers residing in Italy and throughout the world who are potentially interested in Swiss institutional and corporate communications (laws, commercial communications of multinationals, etc.).

${ }^{16}$ For an assessment of the presence and actual use of Italian as a working language of the Swiss public administration cf. for example Andrey; Kübler (2008); Christopher; Zurbriggen (2017) and Pandolfi; Casoni; Christopher (2017, p. 131-138). For the historical stages of the process that put Italian, German and French on an equal footing in the Federal Administration cf. Pini (2017).

${ }^{17}$ German is present in $77.2 \%$ of company websites, French in $51.9 \%$ and English in $49.2 \%$.

${ }^{18}$ On the concept of Italian-speaking Switzerland in historical perspective, see Bianconi (2016) and Morinini (2017).

${ }^{19}$ Val Bregaglia borders on Val Chiavenna,

Valposchiavo on

Valtellina.
Table 3$)^{15}$. In addition, the Ordinance on National Languages and Understanding between Language Communities (Art. 7 (1-2)) recommends quotas for the representation of language communities to be targeted for employees in units of the federal administration. These quotas are established on the basis of the values of the main languages resulting from the censuses, with the target quota for Italian set in a range between 6.5 and $8.5 \%$. In 2012, Italian speakers employed in the federal administration represented $6.7 \%$ of the staff (CHRISTOPHER; ZURBRIGGEN, 2017, p. 74-75), so the quota is respected, even though Italian necessarily has a reduced function as a working language of the administration compared to German and French ${ }^{16}$. An indicator of the functional status of federal Italian as a language of business communication may be the number of websites published in this language, among others. Out of a total of 1,525 websites of Swiss companies active nationally and internationally, $15.9 \%$ are at least partially translated into Italian (PANDOLFI; CASONI; CHRISTOPHER, 2017, p. 128129): a rate of use that places Italian in fourth place among the most used languages on the websites of Swiss companies; a position far removed from other national languages and English (much more widely used ${ }^{17}$ ), but not threatened by other languages.

\section{Italian in Swiss Italian}

In order to refer to the Swiss territories where Italian is the traditional and majority language (Canton Ticino and Grigionitaliano, i.e. the Italian-speaking valleys of Canton Graubünden Moesa, Calanca, Val Bregaglia and Valposchiavo), the term "Italian Switzerland"18 is commonly used in common political and scientific language. Italian-speaking Switzerland is not a geographically united territory. Only Ticino and the Moesa and Calanca valleys form a coherent territory, while Val Bregaglia and Valposchiavo are isolated, although they always border on an Italian-speaking territory (via the national border with Italy, ${ }^{19}$ which also applies to Ticino and the Moesa valley). Italian-speaking Switzerland is not even a single political entity, but comprises two different cantonal language regimes: the Canton of Ticino is officially monolingual, the Canton of Graubünden is officially trilingual (with German and Romansh 
alongside Italian). The two communities that make up Italianspeaking Switzerland also have different populations: Ticino has around 250,000 Italian speakers, the Grigionitaliano around 10,000. For all these reasons, the statistical data for the two regions that make up Italian-speaking Switzerland will be treated separately.

\section{The Canton of Tessin}

Table 6 illustrates the position of the main languages in Canton Ticino and the distribution between monolingual and bilingual speakers (i.e. speakers who declare another main language alongside Italian).

Table 6 - Main languages in Canton Ticino, percentage of the population, 2010-12.

\begin{tabular}{lccc}
\hline & Total & Monolinguals & $\begin{array}{c}\text { Bilinguals with } \\
\text { Italian }\end{array}$ \\
\hline Italian (or Tissino dialect) & 87,8 & 70,9 & - \\
German (or Swiss-German dialect) & 11,1 & 5,0 & 5,9 \\
French (or patois romand) & 5,3 & 0,7 & 2,5 \\
Romansh & 0,1 & $*$ & $*$ \\
Serbian / Croatian & 3,0 & 1,1 & 1,5 \\
English & 3,0 & 0,5 & 0,8 \\
Portugese & 2,9 & 1,4 & 1,3 \\
Spanish & 2,2 & $*$ & $*$ \\
Other non-national languages & 4,7 & 2,5 & $*$ \\
Total population : 284 495 & & & \\
\hline
\end{tabular}

${ }^{20}$ With the exception of the Lusophones, among whom we find a slight majority of monolingual speakers.

\footnotetext{
${ }^{21}$ On the qualitative characteristics of the varieties of Italian as a second language of non-Italian speaking immigrants (foreigners and German-speaking Swiss) in the Canton of Ticino v. Gulàcsi Mazzuchelli (2005).
}

* = unpublishable data (insufficient sample quantity)

Source: Swiss Federal Statistical Office.

Italian occupies a lasting hegemonic position in relation to other national and non-national languages. Indicative of the vitality of the language in its territory are the absolute $(249,771)$ and relative $(87.8 \%)$ number of speakers, the high percentage of monolingual Italian speakers (70.9\%) and the higher values of bilingual behaviour compared to monolingualism among those who declare another main language alongside Italian. ${ }^{20}$ The latter figure indicates that a significant proportion of allophones living in Ticino adopt Italian alongside their native language. ${ }^{21}$ This trend can be verified by considering Italian as the language of origin according to the nationality variable: $77.2 \%$ of foreigners residing in Ticino (about 75,000 answers) 
${ }^{22}$ Even higher are the percentages of use of Italian in the family (82.9\% of foreigners, again out of a total of about 75,000 replies) and at work $(95.7 \%$ of foreigners who are professionally active, out of about 42,000 replies).

\footnotetext{
${ }^{23}$ It should be remembered that the main language only concerns full competence in the language and does not concern partial competence and therefore intermediate levels of competence in Italian L2. We do not have the space to delve into the aspects that lead to the adoption or nonadoption of Italian by allophone foreigners. In addition to the language of origin, the characteristics of their migratory past should be taken into account: the duration and conditions of residence are determining factors in the acquisition of the local language.
}

\section{${ }^{24}$ The reference} population in 2000 has been harmonized according to the new census criteria since 2010. In the case of family languages, the possibility of multiple responses was also provided for in 2000 , so there are no problems of comparability with 2010-2012. (also) indicate Italian as their main language. ${ }^{22}$ If we exclude the almost 44,000 Italians (and therefore Italian speakers), the effective assimilation of the local language concerns 14,000 foreigners from non-Italian speaking countries, while 17,000 foreigners do not have Italian as their main language. ${ }^{23}$

The trend of languages spoken in the family in diachronicity over a period of twelve years ${ }^{24}$ (Table 7) confirms the vitality of Italian on its territory. Moreover, it shows how Italian is acquiring positions to the detriment of other national language ${ }^{25}$ and dialects, a trend, moreover, already noted in the 1990 national census, the first census which also considered dialects (BIANCONI; BORIOLI, 2004 p. 24-48).

Table 7 - Languages spoken in the family, Canton Ticino, val. \%, 2000 and 2010-2012.

\begin{tabular}{lcc}
\hline & $\mathbf{2 0 0 0}$ & $\mathbf{2 0 1 0 - 2 0 1 2}$ \\
\hline Italian & 74,5 & 78,6 \\
Dialect & 36,7 & 30,7 \\
Swiss-German & 10,1 & 8,6 \\
German & 5,1 & 3,2 \\
French & 5,1 & 3,7 \\
Romansh & 0,2 & 0,1 \\
Non-national languages & 9,9 & 13,6 \\
Total population & $\mathbf{2 4 4} \mathbf{6 4 6}$ & $\mathbf{2 8 3} \mathbf{4 7 8}$ \\
\hline
\end{tabular}

Source: Swiss Federal Statistical Office.

These data lead us to explore two themes in greater depth: the subdued and declining presence of non-territorial national languages - in particular German (diasystem, i.e. standard German and Alemannic dialects together) and the situation of dialectophony in Ticino.

\section{Italian and German in Canton Ticino}

German is historically the most present non-territorial language in Ticino: the presence of a German-speaking community (Swiss and foreigners) is of long duration, for the well-known reasons of territorial contiguity and socioeconomic order, German being the central national language for the economy ${ }^{26}$ and the first language of tourism, either transient or residential (especially in the Locarno region). 
${ }^{26}$ German (15\%) and Swiss-German (9.6\%) are the most widely used non-local languages at work in Ticino, followed by English (12.1\%) and French (11.7\%); other non-national languages are rarely used (1.9\%).

\section{${ }^{27}$ On the "language question" in Ticino during the 20th century see also the summary by Taddei Gheiler (2004).}

${ }^{28}$ See also, with more nuanced tones, Lurati (1982).

${ }^{29}$ The reappraisal of these aspects also took place on the basis of the essay by Berruto; Burger (1985, see also TADDEI GHEILER, 2004, p. 51-53). The authors analyzed the process of Germanization of the canton on three levels, emphasising its limited scope either demographically (small number of German-speaking residents) or sociolinguistically (use of German limited to a few specific sectors and with little impact on the everyday communication practices of the indigenous community). On the other hand, in linguistic terms, the influence of German is more obvious - and still relevant - especially in the lexicon of the Ticino regional Italian language, an influence which must, however, be seen as "physiological" in the context of Swiss plurilingualism and contact between national languages.

${ }^{30}$ We are interested here in the relationship and the sociolinguistic opposition between
The presence of German and a German-speaking community (representing the majority and hegemonic language at the national level) in Ticino and its relationship with Italian and the Italian-speaking community has given rise, in terms of social and identity, to an ancient and still latent "language question", which has been debated on several occasions in terms of the dreaded "Germanization" of the canton (BIANCONI, $2016^{27}$ ). Although today it is no longer a priority issue, in the 1980s, in a socio-economic climate of 'speculative land and property euphoria' (BIANCONI, 1994a, p. 18), percentages of German similar to the current rates led to fears of a risk of language substitution or at least a risk of a shift in the community repertoire towards a bilingual Italian-German configuration. Bianconi ${ }^{28}$, in a 1982 paper (p. 110), expressed the fear that Ticino was "ready to become a 'country without" identity, culture and language. Later, Bianconi returned to his examination of the facts ${ }^{29}$ : "the more peaceful reading of these data, the evolution of my concept of identity and the positive evaluation of bilingualism and plurilingualism, enabled me to overcome the apocalyptic position and to read positively the changes in reality" (BIANCONI, 1994a, p. 18).

\section{Italian and dialect in Canton Ticino}

Italian and dialect ${ }^{30}$ have coexisted for a long time in Ticino. Among the speakers the awareness of functional bilingualism, of a different use and social status of the two codes is early ${ }^{31}$. If we look at the development of the dialectophony in Ticino over the last few decades, we see a continuous loss of speakers which corresponds to an increasing diffusion of Italian, favoured by multiple extralinguistic factors (industrialization and tertiarization of the economy, higher level of education, immigration). The situation in Ticino is similar to that observed in Italy (D'AGOSTINO, 2007; VIETTI; DAL NEGRO, 2012). One difference is, however, the rapid decline of the dialect, which has led to talk of a 'collapse' and a situation of 'the beginning of degradation' (MORETTI, 1999). Table $8^{32}$ shows the figures for dialect use in the families of Swiss residents (i.e., the most solid and traditional situation for language transmission). 
the two codes. For this reason, we speak generically of "dialect" without taking into account the significant differences between local dialects, for which we refer to the numerous works of the Centre for Dialectology and Ethnography (www.ti.ch/cde).

\footnotetext{
${ }^{31}$ Bianconi (2013) documents the uses and forms of popular Italian as a lingua franca of the lower social classes since the $16^{\text {th }}$ century.

32 The different shades of grey in the background correspond to different sources and data collection criteria. Even if only partially comparable, the data remains indicative for the trend. For sources and criteria of detection see Moretti (1999, p. 71), Bianconi (1995, p. 63), Bianconi; Borioli $(2004$, p. 50) and Pandolfi et al., (2016, p. 264).
}

${ }^{33}$ Either alternate use of Italian and dialect depending on the interlocutor and the situation, or codeswitching.
Table 8 - Development of dialectophony in Ticino, in the family, percentage of the Swiss population, 1976-2012.

\begin{tabular}{ccccc}
\hline 1976 & 1990 & 2000 & $\begin{array}{c}2000 \\
\text { (harmonized) }\end{array}$ & $\begin{array}{c}\text { 2010-2012 } \\
\text { (pooling) }\end{array}$ \\
\hline 83,1 & 56,8 & 44,6 & 35,0 & 29,5 \\
\hline
\end{tabular}

Source: Swiss Federal Statistical Office

While there was still a strong dialectophony in 1976 ("tanto forte da non avere che pochi paralleli nella situazione d'Italia", MORETTI, 1999, p. 57), there was a noticeable decline in the number of speakers over a period of 14 years (26.3 percentage points) and continued in the following decades. To date, the use of Italian and the dialect in the family and at work is attested by the figures in Table 9 .

Table 9 - Italian and dialect in Ticino, in family and at work, percentage of the population, 2010-2012.

\begin{tabular}{lccccc}
\hline & $\begin{array}{c}\text { Tot. } \\
\text { Italian }\end{array}$ & $\begin{array}{c}\text { Tot. } \\
\text { Dialect }\end{array}$ & $\begin{array}{c}\text { Dialect } \\
\text { only }\end{array}$ & $\begin{array}{c}\text { Italian and } \\
\text { dialect }\end{array}$ & $\begin{array}{c}\text { Total } \\
\text { population }\end{array}$ \\
\hline Family & 78,6 & 30,7 & 12,1 & 16,3 & 283478 \\
Work & 94,0 & 23,9 & 2,2 & 15,6 & 149096 \\
\hline
\end{tabular}

Source: Swiss Federal Statistical Office.

Today, about one third of the inhabitants of Ticino (also) speak the dialect, bilingual behaviour ${ }^{33}$ prevails over the exclusive use of the dialect in the family and more at work where almost nobody speaks only the dialect. Table 10 shows the use of the dialect in relation to the age of the speakers, a factor relevant to the vitality and maintenance of the language over time.

Table 10 - Dialect use in Ticino in the family according to the age of the speakers, percentage of dialect speakers, 2000 and 2010-12.

\begin{tabular}{cccccccc}
\hline & & $\begin{array}{c}\mathbf{1 5} \text { to } \\
\mathbf{2 5}\end{array}$ & $\begin{array}{c}\mathbf{2 6} \text { to } \\
\mathbf{3 8}\end{array}$ & $\begin{array}{c}\mathbf{3 9} \text { to } \\
\mathbf{4 9}\end{array}$ & $\begin{array}{c}\mathbf{5 0} \text { to } \\
\mathbf{6 4}\end{array}$ & $\begin{array}{c}\mathbf{6 5} \text { and } \\
\text { more }\end{array}$ & $\begin{array}{c}\text { Tot. Dialect- } \\
\text { speaking }\end{array}$ \\
\hline \multirow{2}{*}{ Dialect } & $\mathbf{2 0 0 0}$ & 9,7 & 20,1 & 18,8 & 25,3 & 26,1 & 89841 \\
& $\mathbf{2 0 1 0 - 1 2}$ & 8,7 & 13,1 & 17,7 & 27,2 & 33,3 & 87001 \\
\hline
\end{tabular}

Source: Swiss Federal Statistical Office. 


\begin{abstract}
${ }^{34}$ The structural survey considers the population from the age of 15 onwards. There is therefore a lack of data on the linguistic behaviour of children and pre-adolescents. The ELRC 2014 survey asks a question about the languages that parents speak with their children, but the sample of responses for dialect is too small to draw statistically significant results.
\end{abstract}

\footnotetext{
${ }^{35}$ Reference is made, for example, to the work of Lurati (1976), Bianconi (1980), Bianconi (1994a) and Moretti $(1999,2006)$.

${ }^{36}$ A classic example of diglossia is the bilingual repertoire with the Alemannic dialect and German in the German-speaking region of Switzerland (cf. HAAS, 2004).

${ }^{37}$ In contrast to diglossia, in situations of dilalie (typical of Italian repertoires) there is a functional overlap between varieties in informal domains and in primary socialization, whereas Italian remains the only possible variety in formal domains. Maître (2003) proposes the concept of dilalie (autochthonousFrench dialects) for certain local realities in French-speaking Switzerland.
}

\footnotetext{
${ }^{38}$ At the level of linguistic vitality (internal to the language), there is a general process of Italianization and convergence (or rather advergence, $\mathrm{cf}$. MATTHEIER, 1996, p. 34) of the dialect into Italian. With the term advergence (Advergenz) Mattheier
}

The decline of speakers in all age groups is confirmed and the ageing of the dialectophone population is observed, which corresponds to a reduced transmission of the language to the next generations. ${ }^{34}$ It should be noted, however, that the dialect is not lost as the age of the speakers increases. We can see this by comparing the values of one age group in 2000 and the next group in 2010-2012: for example, those who spoke dialect at age 15 in 2000 still speak it at age 25/27 in 2010-2012 and so on.

Sociolinguistic surveys conducted in the canton of Ticino over the last thirty years ${ }^{35}$ have shown that the community repertoire has gone from a situation of 'classical' diglossia (with a clear distinction of fields of use ${ }^{36}$ ) to a situation of dilalie (BERRUTO, 1987a, p. 70). ${ }^{37}$ The Italian language now covers all communicative functions and is present in all fields of use. The dialect coexists in close contact with the dominant code and fulfils a reduced communicative function while maintaining a relatively large area of use within the family and in certain work contexts. While at a macroscopic level the dialect is losing sociolinguistic vitality (i.e., external vitality ${ }^{38}$ ), there is also a phenomenon of risorgenza (BERRUTO, 2006; "resurgence") of the dialect. As has been observed in Italy in recent years, the dialect (re)appears (unexpectedly) in non-traditional areas of use such as advertising (PANDOLFI, 2005), company sites, radio and TV programmes (not only linguistic). It can be found in professional CVs and it is mainly used alongside Italian and other languages in computer mediated communication (CMC or cybercommunication through computers or smartphones) and social networks (MORETTI, 2006; CASONI, 2011; CASONI; CECCARELLI, 2015).

The phenomenon of risorgenza is significant because the dialect is no longer in direct competition with Italian. We could speak of a recovery of the dialect "from the margins" thinking of the marginal dialectal varieties studied by Moretti (1999) - as a code to be reused for specific discursive functions (especially entertainment) and as a "potential for variation" in the repertoire of speakers (MORETTI, 2006). This is a significant phenomenon of the vitality of the dialect insofar as this variety finds new contexts of use, but it is also a marginal phenomenon from a macroscopic point of view that is not reflected in the 
(1996, p. 34) aims to describe a situation of convergence where most changes are in the direction of a dominant variety, rather than cases where varieties in contact influence each other. In spite of this, the internal structures of the dialect remain intact, whose most characteristic features (e.g., structures of negation, subject clitic pronouns) remain intact and are also found in the productions of poorly skilled speakers (MORETTI, 1999) and in situations of contact and nontraditional use of the dialect (e.g., in written interactions through social networks (cf. CASONI, 2012). On the concept of external and internal "linguistic vitality", see, e.g., Carli (2009). demographic data ${ }^{39}$ where there is no recovery in terms of the number of speakers.

\section{The Grigionitaliano}

The Grigionitaliano has been part of the canton of Graubünden since the $15^{\text {th }}$ century without constituting a separate administrative jurisdiction. ${ }^{40}$ Moreover, the four valleys that make it up - as we have said - do not constitute a geographically united territory, and for various historical and sociolinguistic reasons (well highlighted on several occasions by BIANCONI, 1994b, 1998, 2001), they "represent four different linguistic 'solutions' within the same canton" (MORETTI, 2008, p. 371). ${ }^{41}$ A unifying role in safeguarding and promoting the Italian language and culture is that of Pro Grigioni italiano (www.pgi.ch), an association founded in 1918 and financially supported by the Confederation and the canton. The Italian-speaking community is the smallest of the three language communities in Graubünden and is, so to speak, in a triple minority situation: at cantonal $\mathrm{l}^{42}$ and federal level and in relation to the whole of Italian-speaking Switzerland. Table 11 shows the territorial distribution of Graubünden's three official languages.

Table 11 - Main languages in the Canton of Graubünden, percentage of the population, 2010-2012.

\begin{tabular}{|c|c|c|c|c|c|c|c|}
\hline & $\begin{array}{l}\text { Entire } \\
\text { canton }\end{array}$ & $\begin{array}{c}\text { German- } \\
\text { speaking } \\
\text { region }\end{array}$ & $\begin{array}{l}\text { Romansh- } \\
\text { speaking } \\
\text { region }\end{array}$ & $\begin{array}{l}\text { Italian- } \\
\text { speaking } \\
\text { region }\end{array}$ & $\begin{array}{l}\text { Inside the } \\
\text { territory }\end{array}$ & $\begin{array}{l}\text { Outside the } \\
\text { territory }\end{array}$ & \\
\hline & $\begin{array}{c}\text { Tot. } \\
\text { language }\end{array}$ & $\%$ & $\begin{array}{l}\text { \% reg. } \\
\text { pop. }\end{array}$ & $\%$ reg. pop & $\%$ reg. pop & $\begin{array}{c}\% \text { tot. } \\
\text { language }\end{array}$ & $\begin{array}{l}\% \text { tot. } \\
\text { language }\end{array}$ \\
\hline German & 123659 & 75,7 & 86,2 & 47,3 & 14,6 & 90,1 & 9,9 \\
\hline Romansh & 24951 & 15,3 & 7,5 & 68,0 & $(1,1)$ & 60,5 & 39,5 \\
\hline Italian & 20277 & 12,4 & 6,6 & 5,0 & 88,7 & 52,2 & 47,8 \\
\hline Total pop. & \multicolumn{2}{|c|}{163313} & 129240 & 22199 & 11933 & & \\
\hline
\end{tabular}

${ }^{39}$ See in particular the reduced dialectophony of younger people (Table 10), the main users of social networks and $\mathrm{CMO}$ instruments.

\footnotetext{
${ }^{40}$ Like Italianspeaking Switzerland, the Grigionitaliano concept defines the Italian-speaking
}

\section{Source: Swiss Federal Statistical Office}

( ) Data to be interpreted with caution (reduced sample)

German and Italian are clearly dominant in their respective territories (with values above 85\%). In the Romanshspeaking region, the importance of German alongside the local language must be stressed, while in the Grigionitaliano the presence of German speakers is comparable to that recorded in 
territories of

Graubünden

historically and

culturally, but has no

political or legal value.

${ }^{41}$ The small number of the sample does not allow us to present in detail the situation in the individual valleys. 42 Trilingualism
is a fundamental aspect of the canton of Graubünden, but the first legislative measures to protect and promote the cantonal minority languages date back only to 1997 (Cantonal Law on the Promotion of Culture) and only with the constitutional reform of 2004 did Italian and Romansh become equal to German as cantonal and official languages. On the trilingualism of the canton of Graubünden see Grünert et al. (2008) and the monographic issues of the Quaderni grigionitaliani (QGI, 2008, 2014).

${ }^{43}$ The same trend can be observed for Romansh.

\footnotetext{
${ }^{44}$ On the mother tongue and the concept of the native speaker see Berruto; Moretti; Schmid (1988, p. 12-13) and Berruto (2003, p. 8).
}

Ticino. Slightly more than half of the Italian speakers reside in the Grigionitaliano (and Italian tends to increase in its region, see Table 12), while the others reside mainly in the Germanspeaking region, constituting a significant extraterritorial presence for the scope and cantonal status of Italian. That said, we still observe a reduction in the use of Italian in the family (from 9.9\% to 8.8\%) at the cantonal level between 2000 and $2010-2012^{43}$, in the face of an increase in German and nonnational languages.

The Grigionitaliano is characterized by a particularly marked dialectophony of the indigenous population: Table 12 illustrates that in the family more dialect than Italian is spoken.

Table 12 - Use of Italian and Dialect in the family in the Grigionitaliano, val. \%. 2000 and 2010-2012.

\begin{tabular}{lcc}
\hline & $\mathbf{2 0 0 0}$ & $\mathbf{2 0 1 0 - 2 0 1 2}$ \\
\hline Italian & 43,8 & 49,9 \\
Dialect & 72,1 & 61,8 \\
Total population & $\mathbf{1 1 0 5 1}$ & $\mathbf{1 1 9 2 2}$ \\
\hline
\end{tabular}

Source: Swiss Federal Statistical Office

The Grigionitaliano has always been more conservative of the dialect than Ticino (see BIANCONI; BORIOLI, 2004, p. 97). That said, even in the Grigionitaliano, with a few decades of delay and less rapidly than in Ticino, a gradual reduction in dialectophony can be observed.

\section{Italian as a pluricentric language}

An important question that has emerged in recent years is whether Swiss Italian can be considered as having its own centre of normativization, different from that of Italian from Italy, and whether Italian should therefore be considered as a pluricentric language. In order to explore this question in greater depth, we will examine below some linguistic characteristics of Swiss Italian (hereafter ISui) and the standardization phenomena which differentiate this national variety from the Italian standard of Italy (hereafter IIta), with implications which may indicate the presence of a partially autonomous standard. The discussion focuses on Italian used as a mother tongue ${ }^{44}$ in Switzerland, a national and minority 
language whose characteristics show differences with Italian from Italy, especially at the level of the lexicon (the most studied field at present), but also for certain minor aspects related to morphosyntax and pragmatics.

The concentration on the lexicon in studies on ISui confirms what Berruto (1980, p. 24) has written precisely about the lexical peculiarities of ISui : "il lessico è il luogo per eccellenza di manifestazione della diversità linguistica tra varietà geografiche, e in questo caso nazionali [...], giacché è nel lessico che in primo luogo si riflette la differenza di storia, costumi, assetto istituzionale, usanze, correnti socio-culturali economiche e commerciali, e se vogliamo di mentalità". It is therefore mainly at the lexical level that the national differences that characterise pluricentric languages are manifested.

The lexical and (albeit to a lesser extent) morphosyntactic and pragmatic aspects which differentiate the two national varieties will not be discussed here in detail because they have already been extensively dealt with in various articles to which we refer (BIANCONI, 1980; BERRUTO, 1984; PETRALLI, 1990; PANDOLFI, 2006, 2009, 2010, 2017; DE CESARE, 2017). Here we will deal with the descriptive and theoretical aspects of the manifestation of a new national standard of Italian.

The formation of a Swiss standard can be attributed, firstly, to the presence of the national border between Italy and Switzerland which delimits two politically and socially different realities and, secondly, to the contact of the Swiss variety of Italian with the two other majority national languages, German and French. These elements lead to internal dynamics of linguistic change and renewal, partly shared with the restandardization phenomena of IIta (see, among others, BERRUTO, 2007; CERRUTI, 2009), but sometimes with different results for the two varieties.

The issue of the pluricentricity of Italian, and therefore of the existence of several standardization centres for Italian in the case of a Swiss centre partially autonomous from that of Italy, has (as we have said) recently been discussed in several works (PANDOLFI, 2010, 2011, 2017; BERRUTO, 2011; HAJEK, 2012; CERRUTI; PANDOLFI, 2015), starting from the premise that ISui is the only significant case of Italian as a national and official language of a state outside Italian territory. The specification "outside Italian territory" is intended to indicate 
that the varieties of the Republic of San Marino and Vatican City are not taken into account because, although they are two autonomous States, they are of very small geographical and demographic size and are entirely surrounded by Italian territory, which makes it possible to exclude that they could be a place of standardization and elaboration, even partially, autonomous from the Italian of Italy (cf. BERRUTO, 2011, p. 18).

The regional varieties of Italian from Croatia (Istria) and Slovenia are not included in this discussion either, since in these States, Italian is not an official language at the national level (cf., for example, CLYNE (1989, p. 357-371 and 1992, p. 2-3) on the relationship between national and regional varieties), but the language of an 'official minority' (cf. TOSO, 2008, p. 203-208). In particular, Clyne (1989, p. 358) defines languages as pluricentric when they have 'more than one centre, e.g. several centres, each providing a national variety with its own norm' or, in a new specification, as 'languages with several interacting centres, each providing a national variety with at least some of its own (codified) norms' (Clyne, 2004, p. 358). Typically pluricentric languages are therefore considered to be English, French, German, Spanish, Arabic, but also Serbo-Croatian and Chinese (CLYNE, 1992).

In addition, the pluricentricity of a language is linked to the fact that it represents different national identities. Therefore, the main characteristics of pluricentric languages are (cf. BERRUTO, 2011): a) to have more than one centre of standardization, b) to have more than one national variety, and c) to be linked to a national identity. From this perspective, it is therefore essential to define 'centre' as a place of cultural elaboration and linguistic codification and standardization.

${ }^{45}$ Ammon (2003) defines "language codex" as the result of codification: literary texts, normative grammars, dictionaries, etc., which, by definition, serve as a guide for the correct use of language and for the correction of improper usage and determine the patterns and texts to be followed, the usages and the speakers to be imitated. Regarding models and codes ${ }^{45}$ that support and guarantee standardization emanating from a centre, Ammon (1989, p. 90) proposes a five-point scale of endo-normativity and exonormativity of a language (i.e. the degree of autonomy in the development of codified rules: the more endo-normative a language is, the more autonomous it is in establishing a norm independently of other languages and therefore valid as a standard language): (a) total endo-normativity: models and codes come entirely from within the linguistic community in question; (b) predominant endo-normativity: the codes come entirely from L(angue), but the models are partially external; 
(c) partial endo-normativity: the models and codes are partly internal to L. and partly external; (d) predominantly exonormativity: the codes come entirely from outside, but the patterns are partially internal to L; (c) total exo-normativity: models and codes are entirely external, they come from outside.

According to the degree of endo-normativity, Ammon (1989, p. 91) distinguishes four types of centres (and not five since degree 5 is not considered, the total absence of endonormativity excluding the presence of an autonomous centre) progressively less important as such: full centre (full, o fullfledged, centre), corresponding to degree 1 ; nearly full centre, corresponding to degree 2; half-centre, corresponding to degree 3; rudimentary centre, corresponding to degree 4 .

In addition, Ammon (2005, p. 1540-1541) identifies other factors to be considered in defining the type of centre: for example, the size of the centre, either in demographic terms or in terms of political, economic and cultural prestige and the consequent prestige that the variety propagates and, in particular, the age of the centre, i.e. the period since its establishment and its permanence as a centre. It is therefore necessary to determine whether and to what extent the Swiss centre actually constitutes a place of codification and standardization that is (partially) autonomous from the much larger and more significant centre in Italy. In fact, among the essential criteria with regard to the concept of pluricentric language, it is essential in our case that IIta and ISui constitute two different centres and represent two different national identities. Undoubtedly, the national identities of Italy and Switzerland are different and autonomous.

At present, the ISui standard can be defined as a standard shared by a linguistic community (one of the classical definitions of standard, cf. AMMON, 1989). In this sense the standard shared by the Swiss community is different from the standard and from all varieties of regional Italian, even if the distance is small and limited especially, as we have said, to the lexicon. It is also difficult to determine the minimum distance between two varieties that would allow us to say that they are the product of different standardization centres. Undoubtedly, we can say that, for centuries, the influence of chancelleries with their written tradition has been crucial in the dissemination and consolidation of local 
rules for the use of Italian in Italian-speaking Switzerland (cf. among others, BIANCONI, 1989, 2001, 2016; LURATI, 1992; MARTINONI, 2010). As early as the 19th century, it prepared for the introduction of a new administrative terminology appropriate to the Swiss context into which the territory had been integrated: "[U]n nuovo linguaggio politico [...] una nuova terminologia amministrativa [...] congrua al contesto svizzero in cui il paese risulta ora inserito" (LURATI, 1992, p. 158). Bianconi (2001, p. 197) describes the linguistic characteristics of the ISui, due in particular to the presence of Germanisms and Anglicisms stemming from the political structure and the strong dependence of the cantons of Ticino and Graubünden on the financial centres of northern Switzerland. In addition, the development, since the end of the 19th century, of a local literary tradition of considerable importance has played a major role in consolidating the variety of the ISui.

It can therefore be said that the national identity and the cultural context of Italy and Italian-speaking Switzerland are clearly different and that the linguistic characteristics resulting from this are different in the two countries, and even different in relation to the differentiation between the varieties of regional Italian in Italy. The linguistic peculiarities of the ISui can be explained, in some cases, by the linguistic contact with the other languages of the Confederation (cf. BERRUTO, 2011, p. 23-24) and in other cases by an autonomous evolution of the ISui, often favoured by the phenomena of contact. This variation is in addition to the normal diatopic variation and restandardization phenomena shared by all Italian-Romanic varieties (cf. e.g. CERRUTI, 2009; CERRUTI; CROCCO; MARZO, 2017) and reflects the undeniable cultural, political and administrative autonomy of Switzerland and the cantons of Ticino and Graubünden. In addition, the Italian of both cantons enjoys considerable prestige among the speaker community. In an empirical study on this aspect, Antonini and Moretti (2000) subjected different varieties of Italian to the judgement of speakers from Ticino: the local variety and some regional Italian varieties.

In the judgement of the interviewees, the local variety was considered the most beautiful among the varieties propozed and the most suitable to serve as a model for teaching: "si riscontra un atteggiamento globalmente molto positivo 
nei confronti della varietà locale, vale a dire l'italiano della Svizzera Italiana, che risulta la meglio valutata per quanto concerne la bellezza [...] e l'adeguatezza a fungere da modello d'insegnamento" (ANTONINI; MORETTI, 2000, p. 60). In any case, the responses to the interviews indicate that 'l'italiano della Svizzera italiana non rappresenta compiutamente lo standard [italiano]' (ANTONINI; MORETTI, 2000, p. 61). Thus, the ISui is perceived as 'different' from the Italian standard in Italy, but at the same time it is considered beautiful and fully acceptable. This positive attitude of the speaker community represents an important step towards the autonomy and recognition of ISui as the national variety of Italian (see, among others, DRESSLER, 2003, p. 15; AMMON, 2011, p. 55-56; DARQUENNES; VANDENBUSSCHE, 2015, p. 4).

Considering whether the ISui and IIta standards really correspond to two sociolinguistically different centres refers to the notion of standard language, which is multifactorial and difficult to define unequivocally (see, for example, AMMON, 1989; BERRUTO, 2007). Ammon (1995) studied the notion of standard in relation to the pluricentric nature of German and described its definitional properties.

The most significant property of the standard language is that it is codified, with linguistic norms and model texts constituting the prescriptive reference for use. The standard must also have a supra-regional value that neutralises diatopic variation and is capable of satisfying the highest linguistic needs (cf. Kloss' Ausbausprache). It must also be uniform and invariable and be generally used in written production. Ammon (2017, but also in his earlier work) schematises (Figure 2) the social forces that help to determine the standard in a language and through the processes that institutionalise it in a society.

Ammon (2017, p. 23) states that "The public sphere is [...] naturally one of the primary arenas where the norms of standard varieties become established. The social forces which play a major role in this arena are what I call the model speakers and authors. They produce the model texts. They confirm the existing standard variety norms on the one hand, but are the sources of new norms or of norm changes on the other hand. Once language forms have come to be used regularly in these arenas, they are standard". Model texts" and "model 
Figure 2 - The social forces that determine the standard in a language.

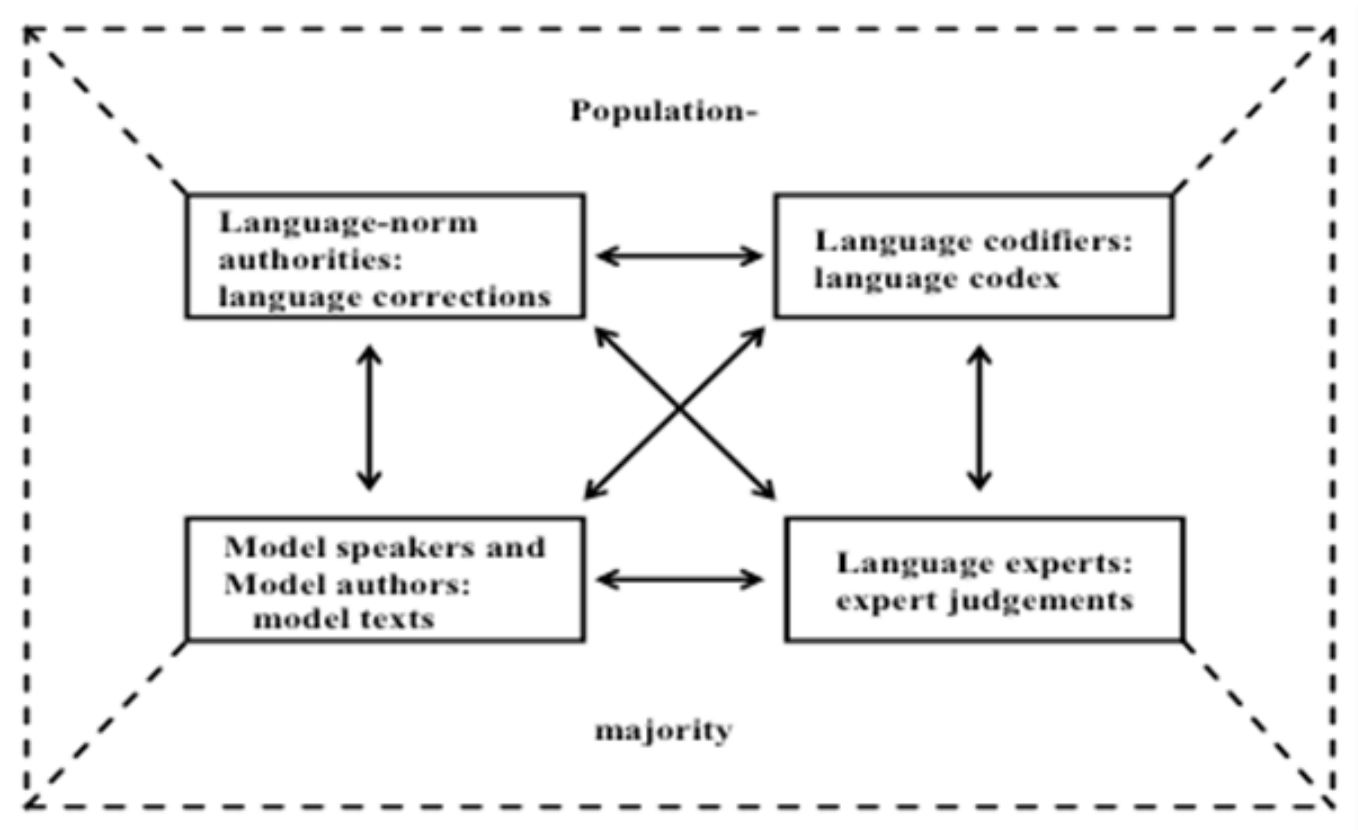

Source: Ammon (2017, p. 22)

speakers" are then considered as such by language experts, and their judgement leads to giving prestige to the variety and to establishing these texts as model texts of the standard language. In the background, there is the majority of the population who can influence the recognition of certain traits as standard by the other primary normative forces at play through the stable use of certain traits.

One of the defining characteristics of the standard is its uniformity and lack of variation, but the reference model texts may change over time and the language authorities may accept new models as the standard (cf. neostandard, BERRUTO, 1987b). If we return to the consideration of the ISui in the light of what has been said, we can state that some of the characteristics of the definition of the standard are fully met for the ISui, as we summarise as follows: variety used by model speakers/writers (radio and television, newspapers and local literary tradition); widespread and prestigious use in the speaker community; variety suitable for teaching and variety also written. 
However, this cannot be said to have led to the explicit codification of a new Swiss standard (if not partially, as we shall see later in the discussion). Indeed, there is no closure of the Ammon quadrilateral (Figure 2): for the time being, there is no competent language authority (comparable to the Accademia della Crusca in Italy or the Académie française in France) that can define the ISui variety as a standard in Switzerland. It could be hypothesized that the Swiss standard variety could be recognized by the Accademia della Crusca, the authority in charge of the Italian language.

According to the considerations outlined so far, Italian can be considered, at least partially, as a language with two centres of standardization, the Swiss centre defined as 'rudimentary centre' (AMMON, 1989, p. 90-91), with predominantly exo-normativity (grade 4), exogenous codes, but with partially endogenous models. This perspective coincides with Hajek's proposal (2012, p. 162-163) which defines Italian as "a weakly pluricentric language", ISui being "a non-dominant variety of a pluricentric language". The advancement from 'rudimentary centre' to 'half-centre' could take place if local standards became more explicit and produced codes in the sense intended by Ammon. Advancement to 'half-centre' is also largely related to the prestige of the national variety and its recognition and acceptance by the speaker community and language authorities (cf. AMMON, 2003, 2017; CLYNE, 1989, p. 458-460).

\section{Modeling the standardisation of Italian In Switzerland}

For modelling the bicentricity of Italian with the relationship between two different standard varieties, we used the cone representation proposed by Auer (2005, p. 32) for German and by Nerbonne et al. (2013) for Dutch standard varieties. A cone representation can be usefully applied to the relationship between the two standard varieties ISui and IIta (Figure 3), taking into account that the standard variety ISui is different from any Italian regional standard in the terms described above.

The specificity of the representation in 0 consists in the fact that the bases of the two cones do not cover the local dialectal bases, as in the representations of Auer and Nerbonne, 
Figure 3 - Conical representation of IIta and IISui.

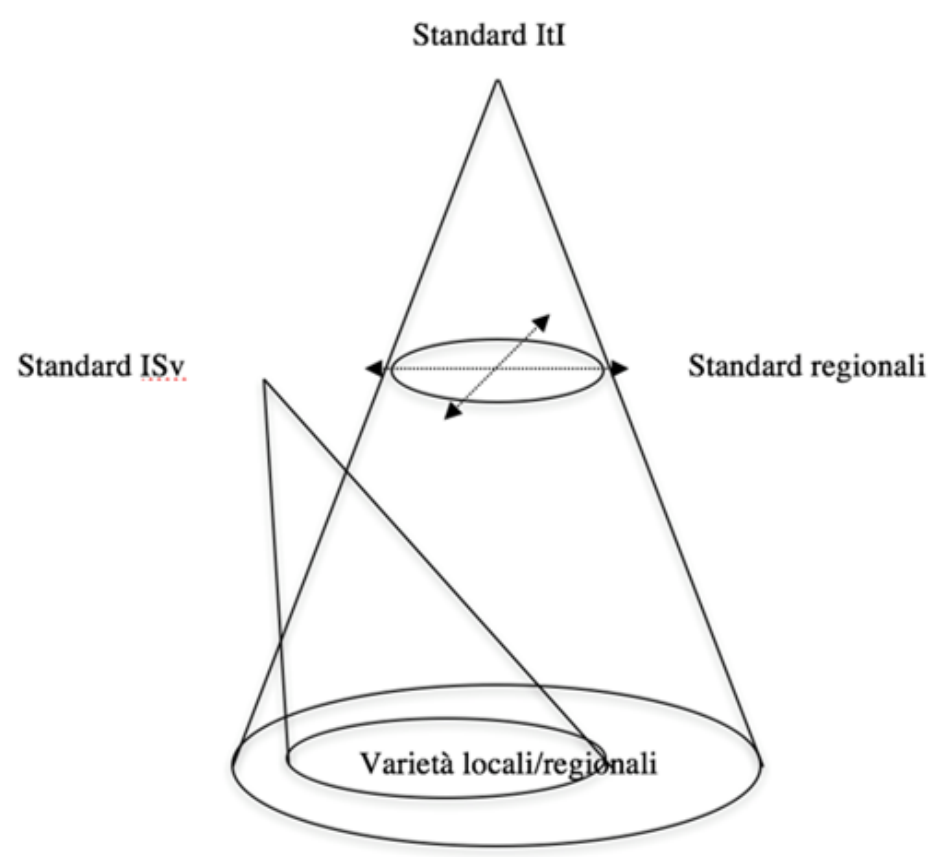

Auer (2005, p. 32)

but the regional varieties of Italian (as in the study by Galli de' Paratesi, 1984, focusing on regional pronunciations): the Swiss cone therefore has a much smaller base because the local varieties are much less numerous than in Italy. The Swiss cone is smaller and almost included in the Italian cone, and its apex is located outside but very close to the Italian cone, being the differences between the two varieties very small. The Swiss cone is at the same level of the Italian regional standards as the ISui must also be considered as one of the Italian diatopic varieties. Both cones develop slightly differently in height from the local varieties towards the vertices, and they represent the

46 The representation by cones has also been proposed for the Italian language of Italy, applied to the Italian-Romanic situation where the standard language and dialects are present (see CERRUTI; REGIS, 2014, p. 106 and BERRUTO, 2016). formation of two different standards, since both cones contain stratifications of varieties of Italian used by groups of speakers (cf. BERRUTO, 2016) which diverge in regional standards. ${ }^{46}$

In fact, the ISui and IIta standards are somewhat different concepts: the Italian standard represents an ideal variety whose rules are codified in grammars and dictionaries, without there being any native speakers who, through spontaneous learning of the language, can meet all the characteristics of 
a standard Italian speaker. In fact, the situation of IIta is best represented by a truncated cone as in Galli de' Paratesi (1984, p. 47). On the contrary, the ISui standard is a native variety actually used by Swiss Italian speakers, whose characteristics have been identified through field observation of the actual linguistic behaviour, both written and oral, of the speakers. It is therefore an example of what Ammon (2003, p. 2) defines as "standard by mere usage". It is therefore not an 'ideal' variety like the IIta standard: in this sense the ISui standard is at the level of Italian regional standards (cf. Figure 3).

\section{Aspects of standardisation of Italian in Switzerland}

On the basis of what has been described so far, we can ask ourselves whether and to what extent the ISui can really be considered as a new national standard that is partially different from the IIta standard. Certainly, we cannot speak of an ISui standard in terms of an autonomous normative codification explicitly expressed in specific grammars and dictionaries. Nevertheless, there are aspects of standardization of the local variety, especially in relation to the lexicon. In this sense, the presence of typical lexemes used in the variety in question and which help to differentiate the ISui from the IIta and from every regional Italian in Italy contributes to the formation of a new national standard.With regard to the standardization aspects of ISui, it is significant that some Helveticisms have been codified in an Italian reference dictionary. In fact, since 1995 the Italian dictionary Zingarelli has labelled some lexical entries as "elvetismi" (34 in editions from 2007 onwards).

Helvetisms could be considered as a regional variant, but there are at least two reasons why the diatopicity of the designation cannot be considered equivalent : a) Switzerland is not a region of Italy, but a separate and autonomous nation, in which one of the four national languages is Italian; b) many of the lexemes considered "elvetismi" by Zingarelli, but also different collections of lexemes used specifically in Switzerland (see, for example, PETRALLI, 1990; PANDOLFI, 2006, 2009) belong to the sphere of administration, politics and law and designate relative institutions and processes, different from those in Italy and its regions. From this point of view, the "elvetismi" hosted in the Zingarelli dictionary monitor the 
normativization of the lexical particularities of the ISui that differentiate it from IIta, thus supporting the hypothesis of a standard lexical norm partially different from IIta.

These lexemes are specific to the ISui at different levels (examples are taken from the Helveticisms present in Zingarelli, 2014): (a) on the diatopic axis, as they indicate specific Swiss institutional realities (e.g., attinenza "originating from", attinenza "place of origin", autopostale "bus belonging to the public transport company of the Swiss post office", this denomination does not exist in Italy); (b) on the diaphasic axis: i.e. they are formal in IIta and of familiar use in ISui (e.g. annunciare "inscribe", annuncio "notification, inscription", bonale "extrajudicial", sedime "building zone"); (c) at the level of lexical genesis by being layers of other Swiss national languages (e.g., azione "promotion" from Aktion, buralista "office employee" from Bürolist).

The contact between the national languages is very intense, particularly through translation, for example in the federal administration or in companies operating throughout Switzerland. However, the contact is not only related to translation, but also occurs: at the social level, through contacts between the different language communities; on a personal level, multilingual speakers are veritable "border-crossers" or "contact persons" who contribute to the construction of networks transcending linguistic borders (see Georges Lüdi, in the preface to the book Pandolfi; Casoni; Bruno, 2016, p. 13: "Indeed, plurilingual speakers are veritable 'border-crossers' or 'boundary-spanners'”' (COSTE, 2003; BARNER-RASMUSSEN, 2015).

Contact, both personal, social and through translation, often leads to the formation of lexemes which exist with the same meaning, etymologically close in the three national languages and which respect the morphology and phonology of the respective languages: these are the so-called "panSwiss triplets" (see BERRUTO, 1984), e.g., Action / action / azione; buralista / Bürolist / buralista. We can therefore state that the process of standardization of the Italian language in Switzerland is taking place according to a model which operates: 
${ }^{47}$ https://www. termdat.bk.admin.ch/ Search/Search (last accessed 12.02.2018).

${ }^{48}$ https://www. bk.admin.ch/ bk/it/home/ documentazione/ lingue/strumentiper-la-redazionee-traduzione/ documentazione-perla-redazione-di-testiufficiali.html (last accessed 12.02.2018).
- from bottom to top: standardization takes place through the well-established use in the speaker community (cf. the 'background' in the Ammon scheme shown in Figure 2), which led to the entry of Helveticisms in the Zingarelli reference dictionary. Widespread use also in the media and the press constitutes a fundamental element of normativization, which also includes the acceptance, sometimes contested by purists, of the particularities of Swiss Italian;

- from top to bottom: standardization is carried out by standardization forces on the part of the federal authorities in the field of administrative and bureaucratic terminology. In fact, many efforts have been made by the federal administration for the standardization of bureaucratic and administrative language in order to create uniformity of denominations for the translation of documents, press releases and official speeches into the three official languages, in accordance with the law. The Termdat ${ }^{47}$ portal, which contains the official terms and the context of use for each of them, contributes to the achievement of this objective. In addition, guidelines have been drawn up for the drafting of official texts, also for Italian ${ }^{48}$ (see EGGER; FERRARI; LALA, 2013 and EGGGER; FERRARI, 2016).

The two phenomena are mutually connected, administrative-bureaucratic terms arrive in the common language through the press and the media and thus become part of the language used by the speaker community to designate everyday realities. The two trends of normativization can therefore lead to a common action on the effective standardization of the autonomous ISui of IIta. It should be taken into account that tendencies towards a new standardization or restandardization which bring an entry into the standard of certain aspects (lexical and morphosyntactic) previously limited to family or informal varieties of Italian (see e.g. BERRUTO, 1987b and recently CERRUTI; CROCCO; 
MARZO, 2017) are underway in both ISui and IIta varieties. In Italy, regional standard varieties are also being developed which coexist with the pan-Italian standard (see, e.g., CERRUTI, 2009; 2014).

\section{REFERENCES}

AMMON, Ulrich. Status and Function of Languages and Language Varieties. Berlin/New York: Mouton de Gruyter, 1989.

Die deutsche Sprache in Deutschland, Österreich und der Schweiz. Das Problem der nationalen Varietäten. Berlin/New York: Mouton de Gruyter, 1995.

. On the Social Forces that Determine what is Standard in a Language and on Conditions of Successful Implementation. In: Sociolinguistica 17. Berlin/New York: Mouton de Gruyter, 2003. p. 1-10. [Também em: Krefter of motkrefter i språknormeringa, Kristiansand, Høyskole Forlaget, Norwegian Academic Press, p. 11-24.]

. Pluricentric and Divided Languages/Plurizentrische und geteilte Sprachen. In: AMMON, Ulrich; DITTMAR, Normart; MATTHEIER, Klaus J.; TRUDGILL, Peter. (org.). Sociolinguistics/Soziolinguistik. Berlin/New York: Mouton de Gruyter, 2005. p. 1536-1543.

A Checklist of Sociolinguistic Language Maintenance Indicators for Diaspora Minorities (with a focus on German examples). In: MORETTI, Bruno; PANDOLFI, Elena María; CASONI, Matteo (org.). Vitality of a Minority Language. Aspects and Methodological Issues. Bellinzona: Osservatorio Linguistico della Svizzera Italiana, 2011. p. 43-63.

Die Stellung der deutschen Sprache in der Welt. Berlin/ München/Boston: de Gruyter, 2015. 
On the social forces that determine what is standard in a language - with a look at the norms of non-standard language varieties. In: PANDOLFI, Elena María; MIECZNIKOWSKI, Johanna; CHRISTOPHER, Sabine; KAMBER, Alain (org.). Studies on Language Norms in Context. Frankfurt am Main: Peter Lang, 2017, p. 17-35.

ANDREY, Stephanie; KÜBLER Daniel. L'italiano a Berna. Rappresentatività e uso delle lingue nell'amministrazione federale. Dati-statistiche e società, n. 4, p. 93-106, 2008.

ANTONINI, Francesca; MORETTI, Bruno. Le immagini dell'italiano regionale. La variazione linguistica nelle valutazioni dei giovani ticinesi. Bellinzona: Osservatorio linguistico della Svizzera italiana, 2000.

AUER, Peter. Europe's sociolinguistic unity, or: A typology of European dialect/standard constellation. In: DELBECQUE, Nicole; VAN DER AUWERA, Johan; GEERAERTS; Dirk (org.). Perspectives on Variation. Sociolinguistic, Historical, Comparative. Berlin/New York: Mouton de Gruyter, 2005. p. 7-42.

BARNER-RASMUSSEN, Wilhelm. What Bicultural-Bilinguals do in Multinational Corporation. In: HOLDEN, Nigel; MICHAILOVA, Sneijina; TIETZE, Susanne. The Routledge Companion to Cross-Cultural Management. New York: Routledge, 2015. p. 142-150.

BERRUTO, Gaetano. Alcune considerazioni sull'italiano regionale ticinese. Quaderni della scuola media, 80.13. Dipartimento della Pubblica Educazione. Bellinzona: Ufficio dell'insegnamento medio, 1980.

Appunti sull'italiano elvetico. Studi linguistici italiani, X, I, p. 76-108, 1984.

. Lingua, dialetto, diglossia, dilalia. In: HOLTUS, Günter; KRAMER, Johannes. Romania et Slavia Adriatica. Festschrift für Žarko Muljačić. Hamburg: Buske, 1987a. p. 57-81.

Sociolinguistica dell'italiano contemporaneo. Roma: Carocci, 1987b [2012]. 
. Note sul repertorio linguistico degli emigrati italiani in Svizzera. Linguistica, n. XXI, p. 61-79, 1991a.

Fremdarbeiteritalienisch: fenomeni di pidginizzazione dell'italiano nella Svizzera tedesca. Rivista di linguistica, n. 3, p. 333-367, 1991b.

Sul parlante nativo (di italiano). In: RADATZ, HansIngo; SCHLÖSSER, Rainer (org.). Donum grammaticorum. Festschrift für Harro Stammerjohann, Tübingen: Niemeyer, 2003. p. 1-14.

Quale dialetto per 1'Italia del Duemila? Aspetti dell'italianizzazione e risorgenze dialettali in Piemonte (e altrove). In: MIGLIETTA, Annarita; SOBRERO, Alberto A. Lingua e dialetto nell'Italia del duemila. Galatina: Congedo, 2006. p. 101-127.

Miserie e grandezze dello standard. Considerazioni sulla nozione di standard in linguistica e sociolinguistica. In: STANDARD E NON STANDARD TRA SCELTA E NORMA., 20-22 ottobre 2005, Bergamo. Anais [Atti del XXX Convegno della Società Italiana di Glottologia]. Roma: Il Calamo, 2007. p. 13-41.

Italiano lingua pluricentrica?. In: OVERBECK, Anja; SCHWEICKARD, Wolfgang; VÖLKER, Harald. Lexikon, Varietät, Philologie. Gunter Holtus zum 65. Geburtstag. Tübingen: Mouton de Gruyter, 2011. p. 15-26.

L'italiano degli svizzeri. Texto da conferência dada na "Nuit des langues" em Berne (Bernerhof), no 8 de novembro de 2012. Disponível em: http://www4.ti.ch/fileadmin/DECS/ DCSU/AC/OLSI/documenti/BERRUTO-2012-Italiano-deglisvizzeri-Berna-conferenza.pdf. Acesso em: 26 mar. 2018.

$\mathrm{Su}$ geometrie sociolinguistiche e modellizzazioni del contatto in ambito italo-romanzo. In: BOMBI, Raffaella; ORIOLES, Vicenzo. Lingue in contatto. Contact linguistics. Roma: Bulzoni, 2016. p. 29-49.

BURGER, Harald. Aspetti del contatto fra italiano e tedesco. Archivio storico ticinese, XXVI, n. 101, p. 29-76, 1985. 
. MORETTI, Bruno; SCHMID, Stephan. L'italiano di parlanti colti in una situazione plurilingue. Rivista Italiana di Dialettologia, n. 12, p. 7-100, 1988.

MORETTI, Bruno; SCHMID, Stephan. Interlingue italiane nella Svizzera tedesca. Osservazioni generali e note sul sistema dell'articolo. In: BANFI, Emanuele; CORDIN, Patrizia (org.). Storia dell'italiano e forme dell'italianizzazione. Roma: Bulzoni, 1990. p. 203-228.

BERTHELE, Raphael. Demography vs. Legitimacy: Current issues in Swiss language policy. In: RONAN, Patricia (org.). Perspectives on English in Switzerland. Lausanne: Institut de Linguistique et des Sciences du Langage, 2016. p. 27-51

BIANCONI, Sandro. Lingua matrigna. Italiano e dialetto nella Svizzera italiana. Bologna: Il Mulino, 1980.

. Italiano regionale e dialetto nella Svizzera italiana. In: LA LINGUA ITALIANA IN MOVIMENTO, 26- febbraio - 4 giugno 1982, Firenze, Palazzo Strozzi. Incontri del Centro di studi di grammatica italiana. Firenze: Accademia della Crusca, 1982. p. 99-112.

. I due linguaggi. Storia linguistica della Lombardia svizzera dal '400 ai nostri giorni. Bellinzona: Casagrande, 1989.

. Lingue nel Ticino. Un'indagine qualitativa e statistica. Locarno: Osservatorio linguistico della Svizzera italiana, 1994a.

Spostamenti della frontiera linguistica italiano-tedesco nel Ticino e nei Grigioni?. Babylonia, n. 1, p. 18-25, 1994 b.

. L'italiano in Svizzera. Secondo i risultati del Censimento federale della popolazione 1990. Locarno: Osservatorio linguistico della Svizzera italiana, 1995.

Plurilinguismo in Val Bregaglia. Locarno: Osservatorio linguistico della Svizzera italiana, 1998.

Lingue di frontiera. Una storia linguistica della Svizzera italiana dal Medioevo al 2000. Casagrande: Bellinzona, 2001. 
. L'italiano lingua popolare. La comunicazione scritta e parlata dei 'senza lettere' nella Svizzera italiana dal Cinquecento al Novecento. Firenze/Bellinzona: Accademia della Crusca/ Edizioni Casagrande, 2013.

. Tre momenti di storia dell'italiano comune. Studi Italiani di Lingustica Teorica e Applicata (SILTA), XLV, n. 3, p. 419-437, 2016.

; BORIOLI Matteo. Statistica e lingue. Un'analisi dei dati del Censimento federale della popolazione 2000. Bellinzona: Ufficio di statistica/Osservatorio linguistico della Svizzera italiana, 2004.

CARLI, Augusto. Le concept de "vitalité linguistique" à l'exemple des "langues minoritaires", des "langues moins utilisées" et des "langues majoritaires". In:STICKEL, Gerhard (org.). National and European Language Policies. Contributions to the Annual Conference 2007 of EFNIL in Riga, Frankfurt am Main/ New York: Peter Lang, 2009. p. 103-113.

CASONI, Matteo. Italiano e dialetto al computer. Aspetti della comunicazione in blog e guestbook della Svizzera italiana. Bellinzona: Osservatorio linguistico della Svizzera italiana, 2011.

CASONI, Matteo. Commutazioni italiano-dialetto nella comunicazione mediata dal computer della Svizzera italiana. In: LA VARIAZONE NELL'ITALIANO E NELLA SUA STORIA. VARIETÀ E VARIANTI LINGUISTICHE E TESTUALI, 5-7 ottobre 2010, Napoli. Anais [Atti dell'XI Congresso SILFI Società Internazionale di Linguistica e Filologia Italiana]. Firenze: Cesati, 2012. p. 265-275.

; CECCARELLI, Giovannna. Al post del dialetto. Posizione, funzioni, caratteristiche del dialetto trasmesso attraverso il computer e altri media nella Svizzera italiana. In: MARCATO, Gianna (org.). Dialetto parlato, scritto, trasmesso. Padova: CLUEP, 2015. p. 251-265.

; CHRISTOPHER, Sabine; PANDOLFI, Elena Maria; BRUNO, Danilo. Le lingue in Svizzera, Addendum. Analisi dei dati dell'Inchiesta tematica sulla lingua, la religione e la cultura (ILRC) 2014. Bellinzona; Osservatorio linguistico della Svizzera italiana. Em preparação. 
CERRUTI, Massimo. Strutture dell' italiano regionale. Morfosintassi di una varietà diatopica in prospettiva sociolinguistica. Frankurt am Main: Peter Lang, 2009.

$\mathrm{Su}$ italiano regionale standard e italiano regionale 'composito', da un singolo punto di osservazione. In: DETTORI, Antonietta (org.). Dalla Sardegna all'Europa. Lingue e letterature regionali. Milano: Franco Angeli, 2014. p. 438-455.

; CROCCO, Claudia; MARZO, Stefania (org.). Towards A New Standard: Theoretical and Empirical Studies on the Restandardization of Italian. Berlin: Mouton de Gruyter, 2017.

; PANDOLFI Elena Maria. Standard coesistenti nell'italiano contemporaneo: i casi di solo più e non più+infinito. In: JEPPESEN KRAGH, Kirsten; LINDSCHOUW, Jan (org.). Les Variations diasystémiques et leurs interdépendances dans les langues romanes. Strasbourg: Eliphi, 2015. p. 465-478.

; REGIS Riccardo. Standardization patterns and dialect/ standard convergence: a North-Western Italian perspective. Language in Society, n. 43, n.1, p. 83-111, 2014

CHRISTOPHER, Sabine; ZURBRIGGEN; Seraphina. Implementation of multilingual status and acquisition planning in the Swiss Federal Administration. In: PANDOLFI, Elena María; MIECZNIKOWSKI, Johanna; CHRISTOPHER, Sabine; KAMBER, Alain (org.). Studies on Language Norms in Context, Duisburg Arbeiten zur Sprach- und Kulturwissenschaft. Frankfurt am Main: Peter Lang, 2017. p. 73-99.

CLYNE, Michael. Pluricentricity: National Variety. In: AMMON, Ulrich (org.). Status and Function of Languages and Language Varieties. Berlin/New York: Mouton de Gruyter, 1989. p. 357-371.

(org.). Pluricentric Languages: Differing Norms in Different Nations. Berlin/New York Mouton de Gruyter, 1992.

Pluricentric Languages. In: Handbooks of linguistics and communication science. Sociolinguistics vol. 3. Completely rev. and extended edition. Berlin/New York Mouton de Gruyter, 2004. p. 296-300. 
COSTE, Daniel. Enjeux et défis pour une éducation plurilingue. In:SEDIFRALE XII, MONDIALISATION ET HUMANIE - LES ENJEUX DU FRANÇAIS, junho 2001, Rio de Janeiro. Anais [Actes du 12e congrès latinoaméricain des professeurs et chercheurs de français langue étrangère, $t$. I, Les politiques linguistiques]. Rio de Janeiro: APFERJ, 2003. p. 101-104.

D'AGOSTINO, Mari. Sociolinguistica dell'Italia contemporanea. Bologna: Il Mulino, 2007.

DARQUENNES, Jeroen; VANDENBISSCHE Wim. The standardization of minority languages - introductory remarks. Sociolinguistica, n.29, Issue 1, p. 1-16, 2015.

DE CESARE, Anna-Maria. L'italiano giornalistico della Svizzera (italiana): caratteristiche morfosintattich. Studi Italiani di Linguistica Teorica e Applicata, XLV, 3, p. 453-464, 2016

DE FLAUGERGUES, Amélie. Pratiques linguistiques en Suisse. Premiers résultats de l'Enquête sur la langue, la religion et la culture 2014. Neuchâtel: Office fédéral de la statistique, 2016. Disponível em : https://www.bfs.admin.ch/bfs/fr/home/statistiques/ catalogues-banques-donnees/publications.assetdetail.1000171. html. Acesso em: 26 mar. 2018.

DRESSLER, Wolfgang U. Dallo stadio di lingue minacciate allo stadio di lingue moribonde attraverso lo stadio di lingue decadenti: una catastrofe ecolinguistica considerata in una prospettiva costruttivista. In: VALENTINI, Ada; MOLINELLI, Piera; BERNINI; Giuliano (org.). Ecologia linguistica. Roma: Bulzoni, 2003. p. 9-25.

EGGER, Jean-Luc; FERRARI, Angela; LALA, Letizia (org.). Le forme linguistiche dell'ufficialità. L'italiano giuridico e amministrativo della Confederazione Svizzera. Bellinzona: Casagrande, 2013.

EGGER, Jean-Luc; FERRARI, Angela. L'Italiano federale svizzero: elementi per una ricognizione. Studi Italiani di Linguistica Teorica e Applicata, XLV, 3, p. 499-523, 2016.

FRANCESCHINI, Rita; MÜLLER, Myriam; SCHMID, Stephan. Comportamento linguistico e competenza dell'italiano in 
immigrati di seconda generazione: un'indagine a Zurigo. Rivista italiana di dialettologia, n. 8, p. 41-72, 1984.

GALLI DE' PARATESI, Nora. Lingua toscana in bocca ambrosiana. Tendenze verso l'italiano standard: un'inchiesta sociolinguistica. Bologna: Il Mulino, 1984.

GRÜNERT, Matthias; PICENONI, Mathias; CATOMAS, Regula; GADMER, Thomas. Das Funktionieren der Dreisprachigkeit im Kanton Graubünden. Tübingen-Basel: Francke, 2008.

GULÀCSI MAZZUCHELLI, Emese. Le varietà di italiano di immigrati non italofoni nel Canton Ticino. In: MORETTI, Bruno (org.). La terza lingua. Aspetti dell' italiano in Svizzera agli inizi del terzo millennio. Volume secondo. Dati statistici e 'varietà dinamiche'. Bellinzona: Osservatorio linguistico della Svizzera italiana, 2005. p. 83-143.

HAAS, Walter. Die Sprachsituation der deutschen Schweiz und das Konzept der Diglossie. In: CHRISTEN, Helen (org.). Dialekt, Regiolekt und Standardsprache im sozialen und zeitlichen Raum. Wien: Praesens, 2004. p. 81-110.

HAJEK, John. (Non-)dominant varieties of a (non-)pluricentric language? Italian in Italy and Switzerland. In: MUHR, Rudolf (org.). Non-Dominant Varieties of Pluricentric Languages: Getting the Picture. In memory of Michael Clyne. Frankfurt am Main: Peter Lang, 2012. p. 155-166.

LURATI, Ottavio. Dialetto e italiano regionale nella Svizzera italiana. Lugano: Banca Solari e Blum, 1976.

La posizione dell'italiano nell'ambito svizzero. Cenobio, 3, xxxI, p. 205-216, 1982.

Il Canton Ticino. In: BRUNI, Francesco (org.). L'italiano nelle regioni. Lingua nazionale e identità regionali. Torino, UTET, 1992. p.143-177.

MAÎTRE, Raphaël. La Suisse romande dilalique. Vox Romanica, n. 62, p. 170-181, 2003. Disponível em : http://periodicals.narr. de/index.php/vox_romanica/article/view/1732/1711. Acesso em: 19.02.2018. 
MARTINONI, Renato. L'Italia in Svizzera. Lingua, cultura, viaggi, letteratura. Padova: Masilio, 2010.

MATTHEIER, Klaus. Varietätenkonvergenz. Sociolinguistica, n. 10, p. 30-52, 1996.

MORETTI, Bruno. Dall'input alla lingua obiettivo: aspetti del continuum dell'italiano 'lingua franca' nella Svizzera germanofona. In: ACTESDUXXeCONGRÈSINTERNATIONAL DE LINGUISTIQUE ET PHILOLOGIE ROMANES, 6-11avril 1992, Université de Zurich, Tome III. Tübingen-Basel: Francke, 1993. p. 558-570.

Ai margini del dialetto. Varietà in sviluppo e varietà in via di riduzione in una situazione di 'inizio di decadimento'. Locarno: Osservatorio linguistico della Svizzera italiana, 1999.

Il laboratorio elvetico In: MORETTI, Bruno (org.). La terza lingua. Aspetti dell'italiano in Svizzera agli inizi del terzo millennio. Volume secondo. Dati statistici e 'varietà dinamiche'. Bellinzona: Osservatorio linguistico della Svizzera italiana, 2005. p. 17-79.

Nuovi aspetti della relazione italiano-dialetto in Ticino. In: SOBRERO, Alberto A.; MIGLIETTA, Annarita. Lingua e dialetto nell'Italia del duemila. Galatina: Congedo, 2006. p. 31-48.

Il 'laboratorio grigionitaliano': dal generale al particolare (e un dettaglio qualitativo). Quaderni grigionitaliani, n. 77 , v. 3, p. 371-378, 2008.

; PANDOLFI Elena María. Outlining a vitality index for Italian in Switzerland. In: RAMAT, Paolo; MIOLA, Emanuele. Language contact and language decay. Socio-political and linguistic perspectives. Pavia: IUSS Press, 2011. p. 191-211.

; PANDOLFI, Elena María; CASONI, Matteo (org.). Vitalità di una lingua minoritaria. Aspetti e proposte metodologiche. Vitality of a Minority Language. Aspects and Methodological Issues. Atti del Convegno di Bellinzona, 15 e 16 ottobre 2010. Bellinzona: Osservatorio linguistico della Svizzera italiana, 2011. 
MORININI Ariele. Prima della Svizzera italiana: etnici e geonimi nei sec. XV-XVIII. In: MORETTI, Bruno; PANDOLFI, Elena Maria; CHRISTOPHER, Sabine; CASONI, Matteo (org.). Linguisti in contatto 2. Ricerche di linguistica italiana in Svizzera e sulla Svizzera. Bellinzona: Osservatorio linguistico della Svizzera italiana, 2017. p. 63-75.

NERBONNE, John; VAN OMMEN, Sandrien; GOOSKENS, Charlotte (org.). A corpus of regional Dutch Speech. In: GOOSKENS, Charlotte S.; VAN BEZOOIJEN, Renee. Phonetics in Europe. Perception and Production. Frankfurt am Main: Peter Lang, 2013. p. 205-232.

PANDOLFI, Elena Maria. L'italiano, il dialetto e le altre lingue nella pubblicità della Svizzera italiana. Studi italiani di linguistica teorica e applicata, XXXIV, 2, p. 284-307, 2005.

Misurare la regionalità. Uno studio quantitativo su regionalismi e forestierismi nell'italiano parlato nel Canton Ticino. Bellinzona: Osservatorio linguistico della Svizzera italiana, 2006.

. LIPSI. Lessico di frequenza dell'italiano parlato nella Svizzera italiana. Bellinzona: Osservatorio linguistico della Svizzera italiana, Bellinzona, 2009.

. Considerazioni sull'italiano L2 in Svizzera italiana. Possibili utilizzazioni di un lessico di frequenza del parlato nella didattica dell'italiano L2. In : SOCIÉTÉS EN MUTATION: LES DÉFIS MÉTHODOLOGIQUES DE LA LINGUISTIQUE APPLIQUÉE, 2008. Actes du colloque VALS-ASLA. 2010. p. 111-125.

Contatto o mancanza di contatto nell'italiano della Svizzera italiana. Considerazioni quantitative. LINGUE E CULTURE IN CONTATTO, 18-19 febbraio 2010, Bolzano. Anais [Atti del X Congresso dell'Associazione Italiana di Linguistica Applicata]. Perugia: Guerra, 2011. p. 235-258.

Italian in Switzerland: the dynamics of polycentrism. In: CROCCO, Claudia; MARZO, Stefania; CERRUTI, Massimo. Towards A New Standard: Theoretical and Empirical Studies on the 
Restandardization of Italian. Berlin: Mouton de Gruyter, 2017. p.321-361.

;CASONI, Matteo; BRUNO Danilo. Le lingue in Svizzera. Analisi dei dati dei censimenti federali 2010-2012. Bellinzona: Osservatorio linguistico della Svizzera italiana, 2016.

; CASONI, Matteo; CHRISTOPHER, Sabine. Aspetti dell'italiano in Svizzera: osservazioni e orientamenti di politica e pianificazione linguistica. In: MORETTI, Bruno; PANDOLFI, Elena Maria; CHRISTOPHER, Sabine; CASONI, Matteo (org.). Linguisti in contatto 2. Ricerche di linguistica italiana in Svizzera e sulla Svizzera. Bellinzona: Osservatorio linguistico della Svizzera italiana, 2017. p. 115-144.

; CASONI, Matteo; CHRISTOPHER, Sabine. Indice di vitalità dell'italiano in Svizzera. Un approccio integrato nel quadro della Language Policy and Planning (LPP). Bellinzona: Osservatorio linguistico della Svizzera italiana. Em preparação.

PETRALLI, Alessio. L'italiano in un cantone. Le parole dell'italiano regionale ticinese in prospettiva sociolinguistica. Milano: Franco Angeli, 1990.

PINI, Verio. Anche in italiano! 100 anni di lingua itaiana nella cultura politica svizzera. Bellinzona: Edizioni Casagrande, 2017.

QGI. L'italiano nel Grigioni trilingue: quale futuro?. Quaderni grigionitaliani, n. 77, v. 3, 2008. Acessível em: http://www.e-periodica.ch/digbib/view?var=true\&pid=q gi-001:2008:77::566\#273. Acesso em: 19 fev. 2018.

QGI. L'italiano tra passato e presente. L'Accademia della Crusca in Val Bregaglia (2012-2013). Quaderni Grigionitaliani, n. 83, v. 1, 2014.

ROVERE, Giovanni. Testi di italiano popolare. Autobiografie di lavoratori e figli di lavoratori emigrati. Roma: Centro Studi Emigrazione, 1977. 
. Il plurilinguismo in Svizzera. Quaderni per la promozione del plurilinguismo, n. 33/34, 1982.

SCHMID, Stephan. L'italiano della seconda generazione e i suoi caratteri. In: SCHMID, Stephan (org.). Che lingua parlo? Identikit linguistico del giovane italiano nella Svizzera tedesca. Zurigo: Centro di Studi Italiani, Zurigo, 1990. p. 17-24.

TADDEI GHEILER, Franca. L'italiano in Ticino. Dalla 'questione della lingua' alla linguistica ticinese: un secolo di dibattiti. In: MORETTI, Bruno (org.). La terza lingua. aspetti dell'italiano in Svizzera agli inizi del terzo millennio. Vol. primo. Norma e varietà di lingua in Ticino. Bellinzona: Osservatorio linguistico della Svizzera italiana, 2004. p. 17-182.

TOSO, Fiorenzo. Le minoranze linguistiche in Italia. Bologna: Il Mulino, 2008.

VIETTI, Alessandro; DAL NEGRO, Silvia. Il repertorio linguistico degli italiani: unanalisi quantitativa dei dati ISTAT. In: COESISTENZE LINGUISTICHE NELL'ITALIA PRE- E POSTUNITARIA, 26-28 settembre 2011, Aosta/Bard/Torino. Anais [Atti del XLV Congresso internazionale di studi della Società di Linguistica Italiana (SLI)]. Roma: Bulzoni, 2012. p. 167-182.

WHINNOM, Keith. Linguistic hybridization and the 'special case' of pidgin and creoles. In: HYMES, Dell (org.). Pidginization and creolization of languages. Cambridge: Cambridge University Press, 1971. p. 91-115.

ZINGARELLI, Nicola. Vocabolario della lingua italiana. Bologna: Zanichelli, 2014. 


\section{RESUMO}

\section{Italiano na Suíça: dados estatísticos e variedades sociolinguísticas}

Essa contribuição apresenta as diferentes situações do italiano nos cantões de Ticino (onde uma redução gradual da dialetofonia está ocorrendo) e de Graubünden (onde o dialeto está sendo preservado), assim como a estandardização do italiano suiço, que está ocorrendo através do processo de "padrão por mera utilização" (AMMON, 2003, p. 2). Nesse trabalho, uma série de conceitos teóricos importantes são atualizados: o conceito de dilalie (BERRUTO, 1987) para descrever a sobreposição funcional entre as duas variedades da língua, o pluricentrismo linguístico (CLYNE, 1989), os modelos de estandardização das linguas pluricêntricas (AMMON, 1989) e a representação da bicentralidade (AUER, 2005) do italiano (Itália e Suiça).

Palavras-chave: Italiano suiço. Dialeto. Estandardização. Pluricentrismo.

Bruno Moretti é Doutor em linguística. Professor titular de linguística italiana; é Vice-reitor da Universidade de Berna. Dirigiu o Observatório Linguístico da Suíça Italiana. É autor de inúmeras publicações nas áreas da sociolinguística, pragmática e do plurilinguismo.

Matteo Casoni é pesquisador do Osservatorio linguistico della Svizzera italiana (OLSI). Atua na área da sociolinguística e línguas em contato.

Elena Maria Pandolfi é Pesquisadora do Osservatorio linguistico della Svizzera italiana (OLSI). Atua na área da sociolinguística e línguas em contato. 